\title{
Uji Aktivitas Antimikroba Daun Sirsak (Annona muricata L.) Terhadap Bacillus subtillis dan Eschericia coli
}

\author{
Anita Fibonacci ${ }^{*}$, Hulyadi ${ }^{2}$ \\ ${ }_{1}^{1}$ Program Studi Kimia Fakultas Sains dan Teknologi Universitas Islam Negeri Walisongo Semarang, \\ Indonesia \\ 2Program Studi Pendidikan Kimia Fakultas Matematika dan Ilmu Pengetahuan Alam, IKIP Mataram \\ Lombok, Indonesia \\ *Email: anitafibonacci@walisongo.ac.id
}

\begin{abstract}
Abstrak
Tujuan penelitian ini adalah untuk mengetahui aktivitas antimkroba dari ekstrak daun sirsak terhadap Bacillus subtilis dan Esherichia coli. Ekstrak daun sirsak diperoleh dengan cara ekstraksi menggunakan metode Soxhletasi dengan pelarut n-heksana dan metanol. Subjek dalam penelitian ini adalah ekstrak daun sirsak. Ekstraksi dilakukan dengan metode soxletasi dengan 8 sirkulasi. Identifikasi senyawa antimikroba menggunakan metode cakram/ paper disc. Dari hasil penelitian ekstraksi daun sirsak tersebut membuktikan bahwa ekstrak daun sirsak mempunyai aktivitas antimikroba terhadap Bacillus subtillis dan Eschericia coli.
\end{abstract}

Kata kunci : Annona muricata; Antimicrobes; Bacillus subtillis; Eschericia Coli

\section{Pendahuluan}

Tanaman obat terbukti efektif mengatasi penyakit bakteri salah satunya yaitu tanaman sirsak. Daun sirsak yang mengandung flavonoid, saponin, tanin dan alkaloid ini berpotensi sebagai bahan untuk mencegah penyakit infeksi bakteri (Permatasari, Besung, \& Mahatmi, 2013). Adapun kandungan gizi yang terkandung dari sirsak (Annona muricata. L) antara lain protein 1,00 gr, lemak 0,30 gr, karbohidrat 16,30 gr, kalsium 14 $\mathrm{mg}$, serat 2,00 gr, vitamin A, vitamin B1, vitamin B2, vitamin C (Hamid, 2011).

Daun sirsak (Annona muricata L.) adalah tanaman yang mengandung senyawa flavonoid, tanin, fitosterol, kalsium oksalat, dan alkaloid (Artini \& Wahjuni, 2012). Staphylococcus aureus dan Escherichia coli merupakan bakteri patogen yang paling banyak menyerang manusia. S. aureus merupakan bakteri gram positif yang hidup sebagai saprofit di dalam saluran membran tubuh manusia, permukaan kulit, kelenjar keringat, dan saluran usus, sedangkan E. coli merupakan bakteri

14

Copyright (C) 2018 WJC | ISSN 2621-5985 (online) | ISSN 2549-385X (print)

Volume 1, Nomor 1, 2018 
gram negatif yang banyak ditemukan dalam usus besar manusia sebagai flora normal (Pelezar, 1988).

Penyakit infeksi masih merupakan masalah utama kesehatan di Indonesia (Fadhilah, 2012). Pengobatan infeksi dengan kombinasi antibiotik yang semula dipercaya sebagai obat yang mampu memusnahkan bakteri penyebab infeksi ternyata juga menimbulkan permasalahan baru yaitu munculnya bakteri yang multi resisten (Maryati, Fauzia, \& Rahayu, 2007).

\section{Metode Penelitian}

\section{Alat dan Bahan}

Peralatan yang digunakan antara lain: Seperangkat alat destilasi, seperangkat alat sokhlet, autoclave, oven, cawan petri, mikropipet, gelas beaker, termometer, pipet tetes, blender, loyang, jarum ose, kertas cakram.

Bahan yang digunakan dalam penelitian ini adalah daun sirsak yang diambil dari daerah gunungpati Semarang, akuades, n-heksana, Alkohol 96 \%, media agar, Bacillus subtillis dan Eschericia Coli.

\section{Prosedur Kerja}

\section{Preparasi Sampel}

Sampel daun Sirsak (Annona muricata L.) yang digunakan adalah daun yang sehat dan tidak berjamur. Sampel daun sirsat yang telah diperoleh kemudian dicuci bersih, dipotong-potong dengan gunting kemudian diletakkan menyebar rata di atas loyang, dan dilakukan oven selama 3 jam. Sampel yang telah kering kemudian diblender untuk dibuat menjadi serbuk.

\section{Ekstraksi Sampel}

Daun Sirsak (Annona muricata L.) yang sudah diserbukkan ditimbang 20 gram, kemudian dibungkus menggunakan kertas saring, dan disokhlet menggunakan pelarut $n$-heksana dengan 8 kali sirkulasi. Sokhlet didiamkan selama 24 jam, setelah 24 jam, pasang kembali alat sokhlet menggunakan pelarut metanol. Sokhlet dilakukan dengan 8 kali sirkulasi.

\section{Pengujian Antibakteri}

Pengujian ekstrak daun sirsak dilakukan dengan metode difusi cakram menggunakan kertas cakram berdiamter $6 \mathrm{~mm}$. Cawan petri, jarum ose, tabung reaksi dilakukan sterilisasi menggunakan autoclave. Stok kultur Bacilus subtilis dipipet dan diteteskan ke dalam media agar kemudian diusap secara merata dengan menggunakan jarum ose. Setelah itu, kertas cakram dicelupkan ke larutan ekstrak daun sirsat. Cakram yang telah ditetesi ekstrak dengan konsentrasi berbeda dan antibiotik diletakkan secara teratur pada permukaan media uji dengan menggunakan pinset. Cawan petri disimpan dan dilakukan pengamatan zona bening yang terbentuk. Diameter zona bening yang terbentuk diukur menggunakan penggaris mm. Langkah yang sama dilakukan untuk kultur Eschericia coli.

\section{Hasil Penelitian dan Pembahasan}

Uji aktivitas antimikroba diawali dengan memotong daun sirsak dengan kemudian potongan daun sirsat tersebut diletakkan menyebar rata di atas loyang, kemudian dilakukan pengeringan menggunakan oven. Hal ini dilakukan untuk menghilangkan kadar air dari daun sirsak.

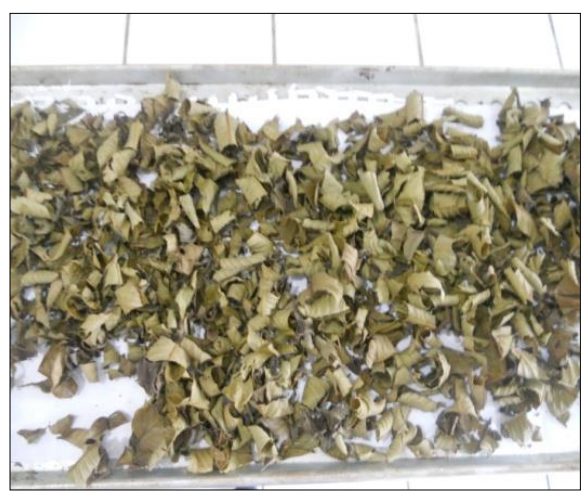

\section{Gambar 1. Potongan Daun Sirsak Kering}

Langkah selanjutnya adalah memblender daun sirsat kering tersebut hingga halus dan timbanglah daun sirsat kering yang telah halus itu sebanyak $20 \mathrm{~g}$, bungkus $20 \mathrm{~g}$ daun sirsat kering tersebut dengan menggunakan kertas saring, 
masukkan ke dalam sokhlet, kemudian memasang rangkaian sokhlet dengan pelarut n-hexana selama 8 kali sirkulasi. Hal ini dilakukan untuk menghilangkan senyawa non polar

Dengan adanya pemanasan, pelarut akan mencapai titik didihnya. Pada saat pelarut mendidih, terjadi kesetimbangan antara fasa uap dengan fasa cair dalam labu alas bulat. Fasa uap keluar melalui pipa menuju ke pendingin dan akhirnya mengembun. Embun menetes pada soxhlet mengenai serbuk daun jambu biji. Pelarut ditampung dalam soxhlet untuk sementara waktu sampai tingginya mencapai tinggi pipa kapiler.

Selama ditampung di dalam soxhlet terjadi kontak yang lebih lama antara bahan yang diekstrak dengan pelarut sehingga pemisahan lebih optimal. Setelah tingginya sama dengan tinggi pipa kapiler, pelarut yang telah membawa komponen yang akan dipisahkan kembali ke labu alas bulat. Pelarut akan mendidih kembali dan menguap menuju kondensor. Komponen yang dipisahkan tetap berada dalam labu alas bulat. Proses ini berlangsung secara terus-menerus sampai komponen yang akan dipisahkan dapat larut dalam pelarut.

Daya hambat suatu senyawa terhadap bakteri tertentu dapat dilihat dari zona bening yang terbentuk (Maryati, et.al., 2007). Hasil uji daya hambat ekstrak daun sirsak terhadap bakteri Bacillus subtillis dan E. Coli dapat dilihat pada Gambar 2 dan Gambar 3.

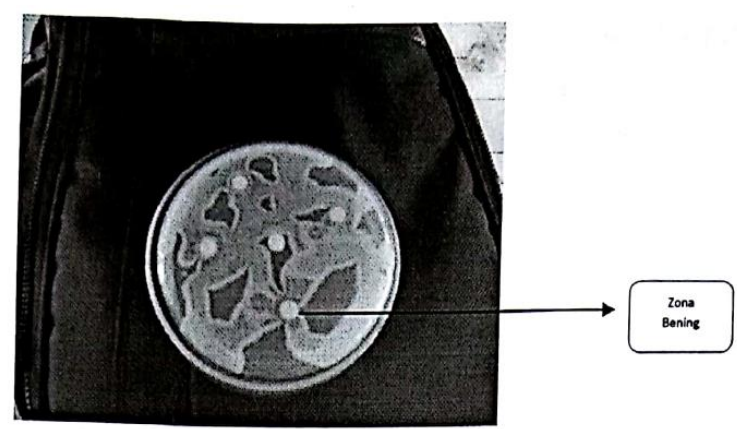

Gambar 2. Hasil Uji antibakteri Pada B. Subtilis

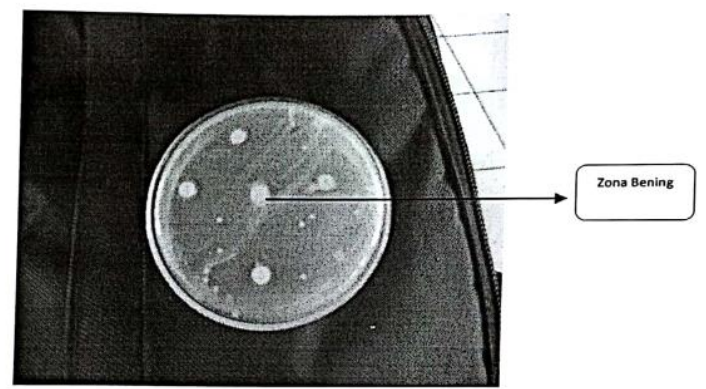

Gambar 3. Hasil uji anti bakteri pada E-coli

Tumbuhan bahan alam memiliki sejumlah senyawa fitokimia yang berperan aktif sebagai anti oksidan. Berdasarkan penelitian terdahulu terhadap tanaman obat dilaporkan mengandung antioksidan terutama disebabkan karna adanya senyawa fenol seperti flavonoid, asam fenolat dan fitokimia. Senyawa-senyawa yang memilki aktivitas antioksidan adalah senyawa fenol yang mempunyai gugus hidroksi yang tersubtitusi pada gugus orto dan para terhadap gugus $-\mathrm{OH}$ dan $-\mathrm{OR}$ (Waji dkk, 2009).

Daun sirsak mengandung alkaloid, tannin dan beberapa kandungan kimia lainnya termasuk annonaceous acetogenins. Kandungan zat - zat tersebut menyebabkan peran daun sirsak sangat fital dalam dunia kesehatan. Pada konsentrasi tinggi, senyawa acetogenin memiliki keistimewan sebagai anti feedent yaitu penghambat pertumbuhan sel kanker. Acetogenin adalah senyawa polyketides dengan struktur 30-32 rantai karbon tidak bercabang yang terikat pada gugus 5methyl-2-furanone. Rantai furanone dalamgugus hydrofuranone pada $\mathrm{C}_{23}$ memiliki aktifitas sitotoksik, dan derivat acetogenin yang berfungsi sitotoksik adalah asimicin, bulatacin, dan squamocin. Squamocin mampu menghambat transport elektron pada sistem respirasi sel, sehingga menyebabkan gradien proton terhambat dan cadangan energi tidak dapat membentuk ATP. Bulatacin diketahui menghambat kerja enzim NADH-ubiquinone reduktase yang diperlukan dalam reaksi respirasi di mitokondria. Dengan komposisi zat diatas daun sirsak memiliki kemampuan dalam menghambat pertumbuhan bakteri hal ini bisa dilihat dari zona bening yang timbul di sekitar paper disk, sebagaimana dapat dilihat pada Tabel 1 . 
Tabel 1. Hasil Uji Sensitivitas Ekstrak Daun Sirsak

Diameter Zona Bening pada B.subtillis

\section{$12 \mathrm{~mm}$}

Kemampuan ekstrak daun sirsak sebagai anti bakteri lebih efektif pada $B$. subtilis jika dibandingkan dengan E.coli, ini bisa kita lihat dari besar diameter zona bening yang dihasilkan. Hasil pengukuran diameter zona bening pada Bacilus subtilis dan E-coli masing - masing sebesar $12 \mathrm{~mm}$ dan $10 \mathrm{~mm}$.

\section{Referensi}

Artini \& Sri Wahjuni (2012). Ekstrak Daun Sirsak (Annona muricata L.) Sebagai Antioksidan Pada Penurunan Kadar Asam Urat Tikus Wistar. JURNAL KIMIA, 6(2), 127-137.

Fadhilah, I. (2012). Uji Aktivitas Antimikroba Ekstrak Daun Sirsak ( Annona muricata L. ) Terhadap Beberapa Mikroba Patogen. Skripsi.

Hamid, B. (2011). Segudang Keampuhan Sirsak Untuk Kesehatan Dan Kecantikan. Jogjakarta: Laksana Trans Media.

Maryati, Fauzia, R. S., \& Rahayu, T. (2007). Uji Aktivitas Antibakteri Minyak Atsiri Daun Kemangi (Ocimum basilicum L.) terhadap Staphylococcus aureus dan Escherichia coli. Jurnal Penelitian Sains \& Teknologi, 8(1), 3038.

Permatasari, G. A. A., Besung, I. N., \& Mahatmi, H. (2013). Daya Hambat Perasan Daun Sirsak Terhadap Pertumbuhan Bakteri Escherichia coli. Indonesia Medicus Veterinus Universitas Udayana, 2(2), 162-169.

Pelezar, J.R.,E.C.S and Chan. 1988. Dasar-Dasar Mikrobiologi, diterjemahkan oleh Hadioetomo, dkk., jilid II, edisi ke-I. Jakarta: UI Press
Pradita Nur, A., Karunia Sari, D., \& Susanto, H., (2013). Integrasi Penyinaran dengan Sinar UV pada Proses Inversi Fase untuk Pembuatan Membran Non-Fouling. Jurnal Teknologi Kimia dan Industri, 2(4), 189-197

Waji, R. 2009. Flavonoid (Quercetin). Makalah Kimia Organik Bahan Alam, Program S2 Kimia Fakultas Matematika Dan Ilmu Pengetahuan Alam. Semanarang: Universitas Hasanuddin 